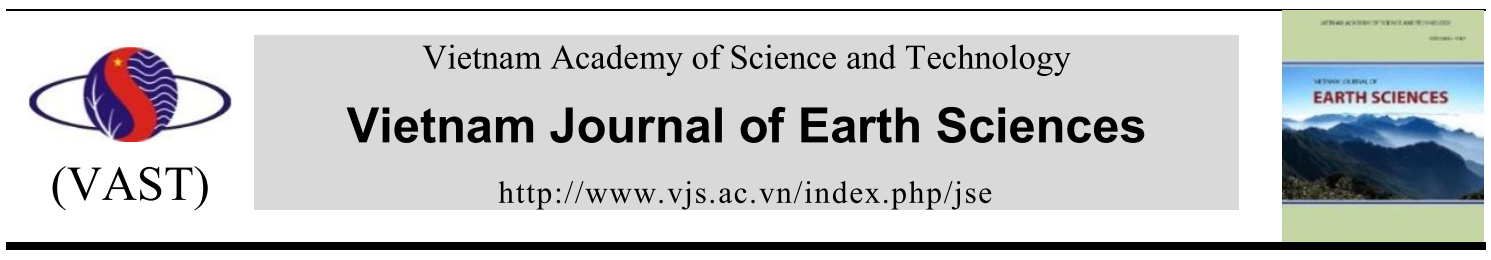

\title{
GIS based frequency ratio method for landslide susceptibility mapping at Da Lat City, Lam Dong province, Vietnam
}

\author{
Dang Quang Thanh¹, Duy Huu Nguyen², Indra Prakash33, Abolfazl Jaafari4, Viet-Tien Nguyen5,6, \\ Tran Van Phong5, Binh Thai Pham ${ }^{1^{*}}$ \\ ${ }^{1}$ University of Transport Technology, Hanoi, Vietnam \\ ${ }^{2}$ Faculty of Geography, VNU University of Science, Hanoi, Vietnam \\ ${ }^{3}$ Department of Science \& Technology, Bhaskarcharya Institute for Space Applications and \\ Geo-Informatics (BISAG), Government of Gujarat, Gandhinagar 382007, India \\ ${ }^{4}$ Research Institute of Forests and Rangelands, Agricultural Research, Education, and Extension \\ Organization (AREEO), Tehran 13185-116, Iran \\ ${ }^{5}$ Institute of Geological Sciences, VAST, Hanoi, Vietnam \\ ${ }^{6}$ Graduate University of Science and Technology, VAST, Hanoi, Vietnam
}

Received 10 October 2019; Received in revised form 24 October 2019; Accepted 13 December 2019

\begin{abstract}
Landslide susceptibility mapping of the city of Da Lat, which is located in the landslide prone area of Lam Dong province of Central Vietnam region, was carried out using GIS based frequency ratio (FR) method. There are number of methods available but FR method is simple and widely used method for landslide susceptibility mapping. In the present study, eight topographical and geo-environmental landslide-conditioning factors were used including slope, elevation, land use, weathering crust, soil, lithology, distance to geology features, and stream density in conjunction with 70 past landslide locations. The results show that $6.27 \%$ of the area is in the very low susceptibility area, $21.03 \%$ in the low susceptibility area, $27.09 \%$ in the moderate susceptibility area and $27.41 \%$ of the area is in the high susceptibility zone and $18.21 \%$ in the very high susceptibility zone. The landslide susceptibility map produced in this study helps to assist decision makers in proper land use management and planning.
\end{abstract}

Keywords: Landslides; Frequency Ratio; GIS; Da Lat City; Vietnam.

C2020 Vietnam Academy of Science and Technology

\section{Introduction}

Landslide is one of the most devastating global natural hazards affecting social economy of the country and livelihoods of the people (Chen et al., 2017). About $14 \%$ of all victims of natural disasters, especially in the hilly regions are due to landslides ((Shirzadi

"Corresponding author, Email: binhpt@utt.edu.vn et al., 2017c; Froude and Petley, 2018)). Topography of the Vietnam is mostly hilly and mountainous. About three-fourth area of Vietnam, which lies in the mountain region, is affected by natural disasters such as flash floods and landslides. This country is in a tropical zone of the monsoon type of climate where severe typhoons occur every year. According to data from the Ministry of 
Natural Resources and Environment, 22\% of the country's landslide occur during monsoon and rainfall is one of the main triggering factors of landslides in this area (Tran et al. 2019). Topography, geology, soil, land use pattern and other geo-environmental factors are responsible for the landslides besides anthropogenic activities in some cases. In the present study, one of the landslide prone area of the Vietnam namely Da Lat City located in Lam Dong Province has been selected as study area.

Technically, current researches in landslide modeling can be grouped into (1) qualitative methods and (2) quantitative methods. Qualitative methods are mainly based on the knowledge and experience of the experts. Analytic Hierarchy Process (AHP)-a common quantitative method, which is based on multi criteria analysis, is an effective tool for dealing with complex decision-making problems in many fields including landslides (Hasekioğulları and Ercanoglu, 2012, Pourghasemi et al., 2012; Kayastha et al., 2013). Quantitative methods include statistic approaches used in the landslide studies are Frequency Ratio (FR) (Lee and Pradhan 2007), Weight Of Evidence (WOE) (Lee and Choi 2004), and Evidential Belief Function (EBF) (Althuwaynee et al., 2012, Pourghasemi and Kerle 2016). With the development of computers and GIS technologies, nowadays, Machine Learning (ML) or Artificial Intelligence (AI) methods such as Artificial Neural Networks (Ermini et al., 2005; Lee et al., 2006), Support Vector Machine (SVM) (Yao et al. 2008, Xu et al. 2012), Logistic Regression (LR) (Ayalew and Yamagishi 2005, Duman et al., 2006), Decision Tree (Yeon et al., 2010, Alkhasawneh et al., 2014) are being used for classification problems and development of landslide susceptibility maps. Hybrid ML approaches which are considered better in some of the cases are also applied in dealing with the landslide problems (Moosavi and Niazi 2016, Pham et al., 2017; Shirzadi et al., 2017a). However, FR approach is still employed in the selection of landslide affecting factors as input and in evaluating results of conventional or AI models. Moreover, FR method is easy and does not require special expertise in dealing with the landslide problems and has been proved good and accurate in the development of landslide susceptibility maps. Akgun et al. (2008) has applied effectively FR method for landslide susceptibility mapping at the Findikli, North East part of Turkey. Jaafari et al. (2014) also used FR method for accurate landslide susceptibility assessment in the Caspian forest, northern Iran. Therefore, this method has been applied to map landslide susceptibility in the present study of Da Lat city of Vietnam for better land use planning and management of this area. Data processing and modeling has been carried out in ArcGIS application.

\section{Study Area}

$\mathrm{Da}$ Lat city is located in the Central Highlands of Vietnam $\left(11^{\circ} 56^{\prime} 25^{\prime \prime}\right.$ North and $108^{\circ} 26^{\prime} 13^{\prime \prime}$ East) (Fig. 1). This city is the capital of the province of Lam Dong. Topography of Da Lat city is mountainous and associated with intervening valleys and minor plains. Northeast part of the city is occupied by mountains namely Lap Be Bac $(1,738 \mathrm{~m})$ and Lap Be Nam (1709 m), northern area by Lang Biang mountain $(2169 \mathrm{~m})$, whereas eastern part by Gio $\mathrm{Hu}$ mountain $(1644 \mathrm{~m})$. Southwestern part is occupied by Pin Hatt (1691 m) and You Lou Rouet $(1632 \mathrm{~m})$ mountains. The low terrain is located in the central area ranging in altitude from 25 to $100 \mathrm{~m}$. Da Lat has two distinct seasons: rainy season from May to October and dry season from November to April. The average annual rainfall is $1562 \mathrm{~mm}$, and humidity is $82 \%$.

There is dense drainage network system in this city. The Dong Nai River is a main river associated with its tributaries namely $\mathrm{Da}$ Nhim River, Da Duong River, and Cam Ly 
River. Land use pattern of the city area is mainly of four types: (1) barren lands, (2) cultivated lands, (3) residential areas, and (4) forest. Day by day due to increase in urbanization and tourism activity forestland is being encroached thus decreasing in terms of surface area. The soil types belong to two main groups: red brown feralite soil distributed at an altitude of 1,000-1,500 $\mathrm{m}$ and a group of humus alisolson at an altitude of $1,000-2,000 \mathrm{~m}$. These soils are occupying relatively lower parts of the area. Alluvial soils are mainly present in the valleys bottom and in the lower plain areas. Geologically, the Da Lat city is made up of Jurassic sediments, Precambrian basement rocks, and late Mesozoic igneous and Cenozoic basaltic rocks (Nguyen et al., 2004).

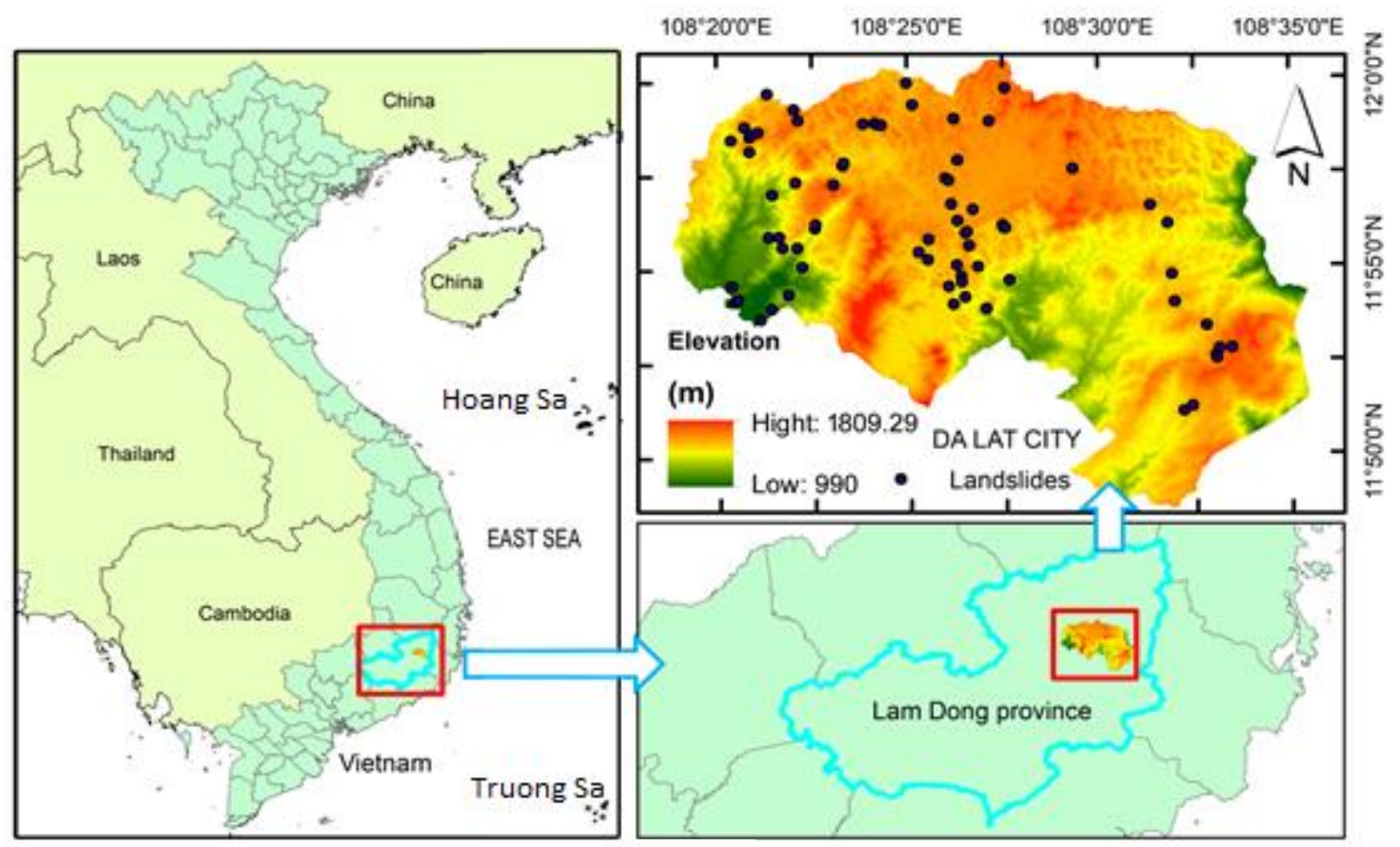

Figure 1. Landslide inventory and location map of the study area
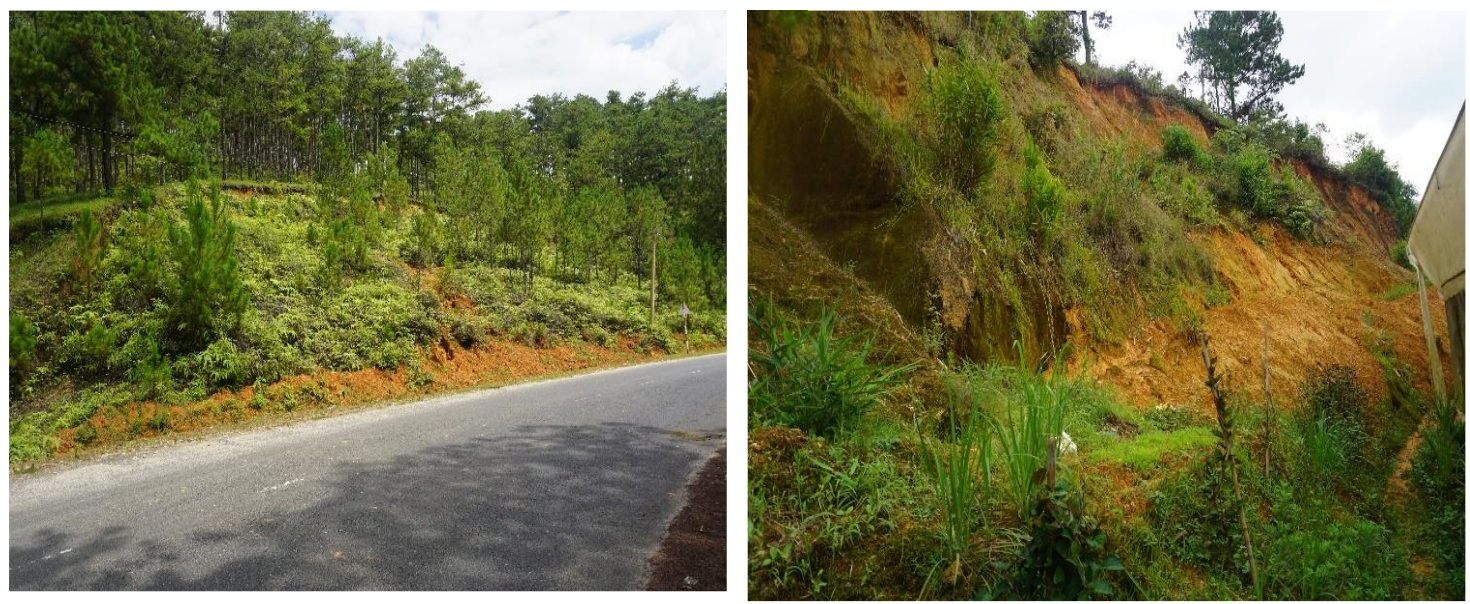

Figure 2. Landslide photos of the study area 


\section{Frequency Ratio (FR) method}

Frequency Ratio (FR) is the ratio of occurrence probability to non-occurrence probability for specific attributes (Shirzadi et al., 2017b). FR method is used to evaluate the landslide susceptibility and presents the relationships between landslide occurrence event and its influencing factor in a given area (Gholami et al., 2018). FR approach is one of the easiest methods of application, and the results are easy to interpret and understand (Shirzadi et al., 2017b). FR values are presented by Equation (1).

$$
F R=\left[\begin{array}{c}
\frac{N_{p i x}\left(S X_{i}\right)}{\sum_{i=1}^{m} S X_{i}} \\
\frac{N_{p i x}\left(X_{j}\right)}{\sum_{j=1}^{n} N_{p i x}\left(X_{j}\right)}
\end{array}\right]
$$

where $\mathrm{N}_{\text {pix }}\left(\mathrm{SX}_{\mathrm{i}}\right)$ and $\mathrm{N}_{\text {pix }}\left(\mathrm{X}_{\mathrm{j}}\right)$ presents the sum of pixels with landslides within the classification of variable $X_{i}$ and $X_{j} . m$ is the sum of layers in the variable $X_{i}, n$ is the sum of a variable that was chosen for the modelling.

In FR method, the ratio shows the landslide occurrence area by the total area. Higher FR values than 1 indicates greater relationship between a landslide and the specific factor's attribute (Pham et al., 2015). In this study, to avoid the difference of classification of factors used, we have used normalized frequency ratio (NFR), which is a normalization of FR values in the range of 0.01 to 0.99 .

To calculate the FR values of classes of factor maps, the conversion of all the vector landslide influencing factor layers into raster (grid) format of each pixel size of $20 \mathrm{~m} \times$ $20 \mathrm{~m}$ was done. In the entire study area, there is of about 3952834 pixels with 72 landslide pixels. Out of these, $70 \%$ of landslides (51 landslide pixels) were used to analyze the FR, and then prepared the final susceptibility map whereas $30 \%$ remaining landslides (21 landslide pixels) were used to validate the performance of the final map as the 70/30 is a popular ratio used in landslide mapping (Lee and $\mathrm{Oh}, 2012$ ).

\section{Data used}

\subsection{Landslide inventory}

Landslide inventory include location, type and mechanism of landslides besides groundmass condition and geo-environmental factors of the area, which is very important data for landslide susceptibility assessment and mapping (Tien Bui et al., 2012a; Tien Bui et al., 2012b; Pham et al., 2019). In this study, landslide inventory map is prepared from the available historical records, Google earth images and field surveys of the national project's code TN18/T13, Vietnam Academy of Science and Technology (VAST). A total of 72 past and present landslides were identified and collected as shown in Fig. 1 and Fig. 2. The most common types of landslides present in the area are rock and debris slides.

\subsection{Factors affecting landslides}

The selection of proper conditioning factor is one of the most critical steps for the landslide susceptibility assessment (Gholami et al., 2018; Dou et al., 2019a, Nguyen et al. 2019, Thai Pham et al., 2019). In the present study, eight conditioning factors are selected namely slope, elevation, land use, lithology, stream density, soil thickness, weathering crust, distance to geology boundary/feature.

Topographic features were extracted from the Digital Elevation Model (DEM) of $20 \mathrm{~m}$ resolution, constructed from the 1:50000 topography map of the area. Soil and geology maps were prepared form the soil survey and geological survey maps. Slope is one of the 
important factors for landslide susceptibility assessment (Chang et al., 2019; Dou et al., 2019b, Nohani et al., 2019; Phong et al.; 2019). Most landslides have direct relationships with the slope angle (Chen et al., 2017; Abedini et al., 2018, Thai Pham et al., 2018; He et al., 2019). In general, moderate slopes between 30 to $45^{\circ}$ are most vulnerable to major landslide occurrences. In this study, slope map is classified into five classes based on natural break classification method in ArcGIS application: 0-5.368, 5.368-12.525, 12.525-19.682, 19.682-27.734, and 27.734$76.045^{\circ}$ (Fig. 3a). Elevation is important as it controls precipitation, vegetation, weathering and stresses (Gorsevski and Jankowski 2010). Elevation map in this area is classified into five classes: $990-1208,1208-1336,1336-$ 1436, 1436-1520, 1520-1809 m (Fig. 3b).

Land use/land cover pattern in the area is one of the important factors in the slope stability as it controls infiltration and soil erosion (Barlow et al., 2003). Land use map of the area was prepared with the help of Google earth images in three major classes: agricultural land, non-agricultural land, and barren land (Fig. 3c). Lithology plays a vital role in the landslide vulnerability studies to landslides (Tien Bui et al., 2015; Pham et al., 2018). Mineral composition and texture of lithological units determine their vulnerability to weathering and deformation. Porosity and permeability of these units determines their water holding capacity infiltration characteristics. Lithology map of this area was prepared from the geological survey map and classified into 11 groups namely Pliocen (group 1), La Nga formation (group 2), Don Duong formation (group 3), Ankroet-Ca $\mathrm{Na}$ complex: phase 2 (group 4), Quaternary (group 5), Neogen (group 6), Ankroet-Ca Na complex: phase 1 (group 7), Din Quan complex (group 8), Xuan Loc formation (group 9), Dak Rium formation (group 10), Ankroet-Ca $\mathrm{Na}$ complex: gangue phase (group 11) (Fig. 3d).

Stream density represents the infiltration and runoff conditions of the surface (Shirzadi et al., 2017c). More runoff is liable to erosion and more infiltration can created hydrostatic pressure and thus can make ground slope venerable to sliding Increasing the stream causes the landslide to increase. Stream density map of this area was classified into 5 groups: $0-0.387, \quad 0.387-0.99,0.99-1.636$, $1.636-2.475$, and $2.475-5.489 \mathrm{~km} / \mathrm{km}^{2}$ (Fig. 3e). Soil thickness is considered as one of the conditioning factors in landslide susceptibility model. Thick soil is more liable to large slides in the association with other geo-environmental factors. Soil thickness map of this area was classified into five classes: $30,30-50,50-70,70-100$, and $>100(\mathrm{~cm})$ (Fig. 3f).

Weathering crust is one of the most important factors in the slope stability. Highly weathered rock/ crust is more vulnerable to sliding (Duc 2013). Weathering crust in this study area was divided into 7 categories namely AIFE2, FesiAI1, FesiAI2, FesiAI3, Quaternary, SiAIFe1, and SiAIFe2 (Figure $3 \mathrm{~g}$ ). Distance to geology boundary/ feature has the inverse proportionality with the landslide occurrence as soil and rocks at geology boundary is often discontinued ( Dou et al., 2015). Five classes of distance buffers have been created from the geological map keeping geological boundary/ feature at the center (Fig. 3h). 
Dang Quang Thanh et al./Vietnam Journal of Earth Sciences 42(2020)
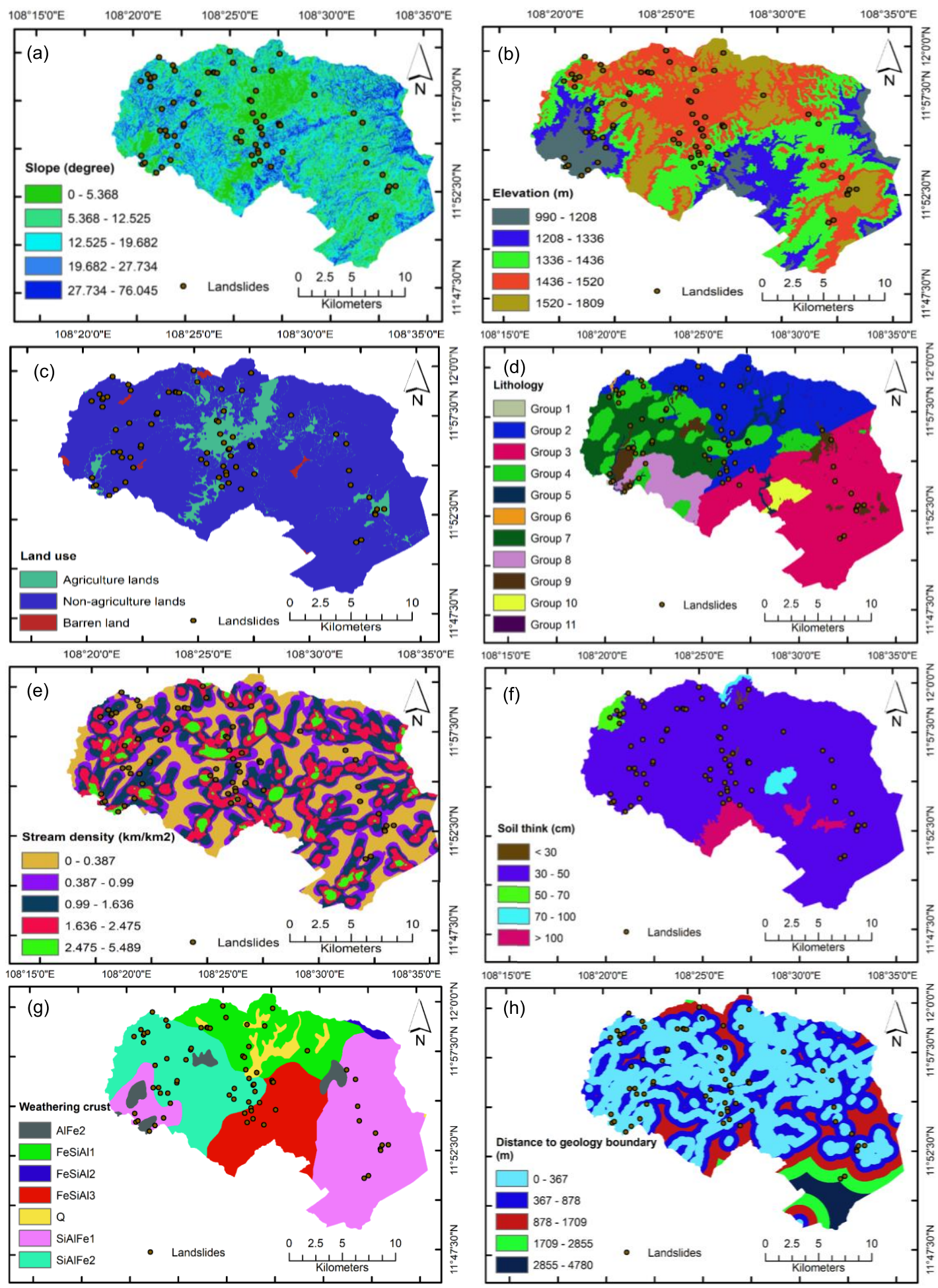

Figure 3. Maps of landslide conditining factors used in this study: (a) slope, (b) elevation, (c) land use, (d) lithology, (e) stream density, (f) soil think, (g) weathering crust, and (h) distance to geology boundaries 


\section{Results and Discussions}

\subsection{Analysis of spatial relationship between landslide occurrences and the conditioning factors}

Spatial relationship between landslide occurrences and the conditioning factors was analyzed as shown in Table 1. In case of slope factor, highest landslides occur in slope class 12.525-19.682 $(\mathrm{FR}=1.25)$. This confirmed the observation of earlier study that moderate to less high slopes are more vulnerable to sliding. In land use, the high FR was concentrated on non-agriculture lands (FR = 8.23). This is also with the agreement with the general observation as more and more encroachment is taking place of agricultural activity for the city development and thus landslide is relatively higher in this land class $(0.82 \%$ landslide). The results of stream density showed that the landslide concentration at the low stream density zone of $0-0.387$ (FR $=1.42)$, as the stream density increases to 2.475-5.489, the occurrence of landslide tends to decrease. The results of FR in the case of elevation factor showed the occurrence of landslide concentrated on the class ranging from 1520.128 to $1809.289 \mathrm{~m}$ as vegetation is less at these elevations due to climate also due deforestation activities. Two groups of Lithology namely group $1(\mathrm{FR}=$ $634.27)$ and group $6(\mathrm{FR}=182.66)$ are more vulnerable to landslides. Weathering crust class: SiAlFe2 $(\mathrm{FR}=0.64), \mathrm{Q}(\mathrm{FR}=0.46)$ and FeSiAl3 $(\mathrm{FR}=0.44)$ are most affected by landslides where ground mass is more weathered. Soil having thickness of 30 to $50 \mathrm{~cm}(\mathrm{FR}=6.28)$ is more affected by landslide. This may be due to the reason with the combination of other geo-environmental factors; otherwise, soil with more thickness $(100 \mathrm{~cm})$ would have been more affected by landslides. Landslide occurs near the geological boundary/feature buffers at 0-367.967 m (FR = 1.42), due to presence of vulnerable planes and associated jointed fracture zones (Table 1).

\subsection{Building landslide susceptibility map}

Landslide susceptibility mapping was done using the FR analysis (Table 1). Firstly, computation of Landslide Susceptibility Index (LSI) was carried out in ArcGIS based on the Equation (2). Secondly, LSI was reclassified into five classes based on natural break method which is a popular technique for classification of landslide susceptibility classes (Constantin et al., 2011) including very low (0.817-3.195), low (3.195-3.964), medium (3.964-4.66), high (4.66-5.477) and very high (5.477-6.918) (Fig. 4).

$$
L S I=\sum_{i=1}^{n} N F R i
$$

where $\mathrm{n}$ is the number of the factors used.

Landslide susceptibility map (Fig. 4) showed that the landslide occurs mainly in the western part of the study area where deforestation activity is more due to tourism development. Thus, this area is more vulnerable to future slides. Part of the east and southeast area is less susceptible to landslides as it is covered mostly by forests thus providing stability to ground soil from landslide. Produced landslide susceptibility map would be helpful to decision-makers in city planning. 
Dang Quang Thanh et al./Vietnam Journal of Earth Sciences 42(2020)

Table 1. FR analysis of landslide conditioning factors

\begin{tabular}{|c|c|c|c|c|c|c|c|}
\hline Factors & Class & Class pixels & Landslide pixels & $\%$ Class & $\%$ landslides & FR & NFR \\
\hline \multirow{5}{*}{ Slope $\left(^{\circ}\right)$} & $0-5.367$ & 812181 & 8 & 0.21 & 0.16 & 0.76 & 0.01 \\
\hline & $5.367-12.525$ & 1054270 & 11 & 0.27 & 0.22 & 0.81 & 0.10 \\
\hline & $12.525-19.682$ & 1054270 & 17 & 0.27 & 0.33 & 1.25 & 0.99 \\
\hline & $19.682-27.734$ & 714860 & 11 & 0.18 & 0.22 & 1.19 & 0.87 \\
\hline & $27.734-76.045$ & 304920 & 4 & 0.08 & 0.08 & 1.01 & 0.52 \\
\hline \multirow{3}{*}{ Land use } & Agriculture lands & 3534809 & 9 & 0.89 & 0.18 & 0.20 & 0.34 \\
\hline & Non-agriculture lands & 393674 & 41 & 0.10 & 0.82 & 8.23 & 0.99 \\
\hline & Others & 24251 & 0 & 0.01 & 0.00 & 0.00 & 0.01 \\
\hline \multirow{5}{*}{$\begin{array}{l}\text { Stream density } \\
\left(\mathrm{km} / \mathrm{km}^{2}\right)\end{array}$} & $0-0.387$ & 1168639 & 21 & 0.30 & 0.42 & 1.42 & 0.99 \\
\hline & $0.387-0.99$ & 845403 & 11 & 0.21 & 0.22 & 1.03 & 0.48 \\
\hline & $0.99-1.636$ & 1047856 & 10 & 0.27 & 0.20 & 0.75 & 0.11 \\
\hline & $1.636-2.475$ & 710373 & 6 & 0.18 & 0.12 & 0.67 & 0.01 \\
\hline & $2.475-5.489$ & 180556 & 2 & 0.05 & 0.04 & 0.88 & 0.28 \\
\hline \multirow{5}{*}{ Elevation (m) } & $990-1208.477$ & 352003 & 4 & 0.09 & 0.08 & 0.90 & 0.38 \\
\hline & $1208.477-1336.993$ & 571150 & 4 & 0.14 & 0.08 & 0.55 & 0.01 \\
\hline & $1336.993-1436.592$ & 1088721 & 11 & 0.28 & 0.22 & 0.80 & 0.28 \\
\hline & $1436.592-1520.128$ & 1290190 & 19 & 0.33 & 0.38 & 1.16 & 0.67 \\
\hline & $1520.128-1809.289$ & 650762 & 12 & 0.16 & 0.24 & 1.46 & 0.99 \\
\hline \multirow{11}{*}{ Lithology } & Group 1 & 1745 & 14 & 0.00 & 0.28 & 634.27 & 0.99 \\
\hline & Group 2 & 1020932 & 7 & 0.26 & 0.14 & 0.54 & 0.01 \\
\hline & Group 3 & 1436529 & 13 & 0.36 & 0.26 & 0.72 & 0.01 \\
\hline & Group 4 & 494711 & 2 & 0.13 & 0.04 & 0.32 & 0.01 \\
\hline & Group 5 & 93327 & 0 & 0.02 & 0.00 & 0.00 & 0.01 \\
\hline & Group 6 & 3026 & 7 & 0.00 & 0.14 & 182.88 & 0.29 \\
\hline & Group 7 & 439989 & 1 & 0.11 & 0.02 & 0.18 & 0.01 \\
\hline & Group 8 & 235281 & 5 & 0.06 & 0.10 & 1.68 & 0.01 \\
\hline & Group 9 & 144303 & 0 & 0.04 & 0.00 & 0.00 & 0.01 \\
\hline & Group 10 & 69166 & 1 & 0.02 & 0.02 & 1.14 & 0.01 \\
\hline & Group 11 & 13825 & 0 & 0.00 & 0.00 & 0.00 & 0.01 \\
\hline \multirow{7}{*}{ Weathering crust } & $\mathrm{AlFe} 2$ & 119005 & 0 & 0.08 & 0.00 & 0.00 & 0.01 \\
\hline & FeSiAll & 633569 & 8 & 0.41 & 0.16 & 0.39 & 0.61 \\
\hline & FeSiAl2 & 21551 & 0 & 0.01 & 0.00 & 0.00 & 0.01 \\
\hline & FeSiAl3 & 640500 & 9 & 0.41 & 0.18 & 0.44 & 0.67 \\
\hline & $\mathrm{Q}$ & 133491 & 2 & 0.09 & 0.04 & 0.46 & 0.72 \\
\hline & SiAlFe1 & 1488814 & 12 & 0.96 & 0.24 & 0.25 & 0.39 \\
\hline & SiAlFe2 & 915921 & 19 & 0.59 & 0.38 & 0.64 & 0.99 \\
\hline \multirow{5}{*}{ Soil thickness $(\mathrm{cm})$} & $<30$ & 11858 & 0 & 0.00 & 0.00 & 0.00 & 0.01 \\
\hline & $30-50$ & 50381 & 4 & 0.01 & 0.08 & 6.28 & 0.99 \\
\hline & $50-70$ & 67898 & 0 & 0.02 & 0.00 & 0.00 & 0.01 \\
\hline & $70-100$ & 171301 & 1 & 0.04 & 0.02 & 0.46 & 0.08 \\
\hline & $>100$ & 3651414 & 45 & 0.92 & 0.90 & 0.97 & 0.16 \\
\hline \multirow{5}{*}{$\begin{array}{l}\text { Distance to geology } \\
\text { feature }(\mathrm{m})\end{array}$} & $0-367.967$ & 2020034 & 37 & 0.51 & 0.73 & 1.42 & 0.99 \\
\hline & $367.967-878.635$ & 1141556 & 12 & 0.29 & 0.24 & 0.81 & 0.57 \\
\hline & $878.635-1709.064$ & 457743 & 0 & 0.12 & 0.00 & 0.00 & 0.01 \\
\hline & $1709.064-2855.24$ & 187461 & 2 & 0.05 & 0.04 & 0.83 & 0.58 \\
\hline & $2855.24-4780.094$ & 146033 & 0 & 0.04 & 0.00 & 0.00 & 0.01 \\
\hline
\end{tabular}




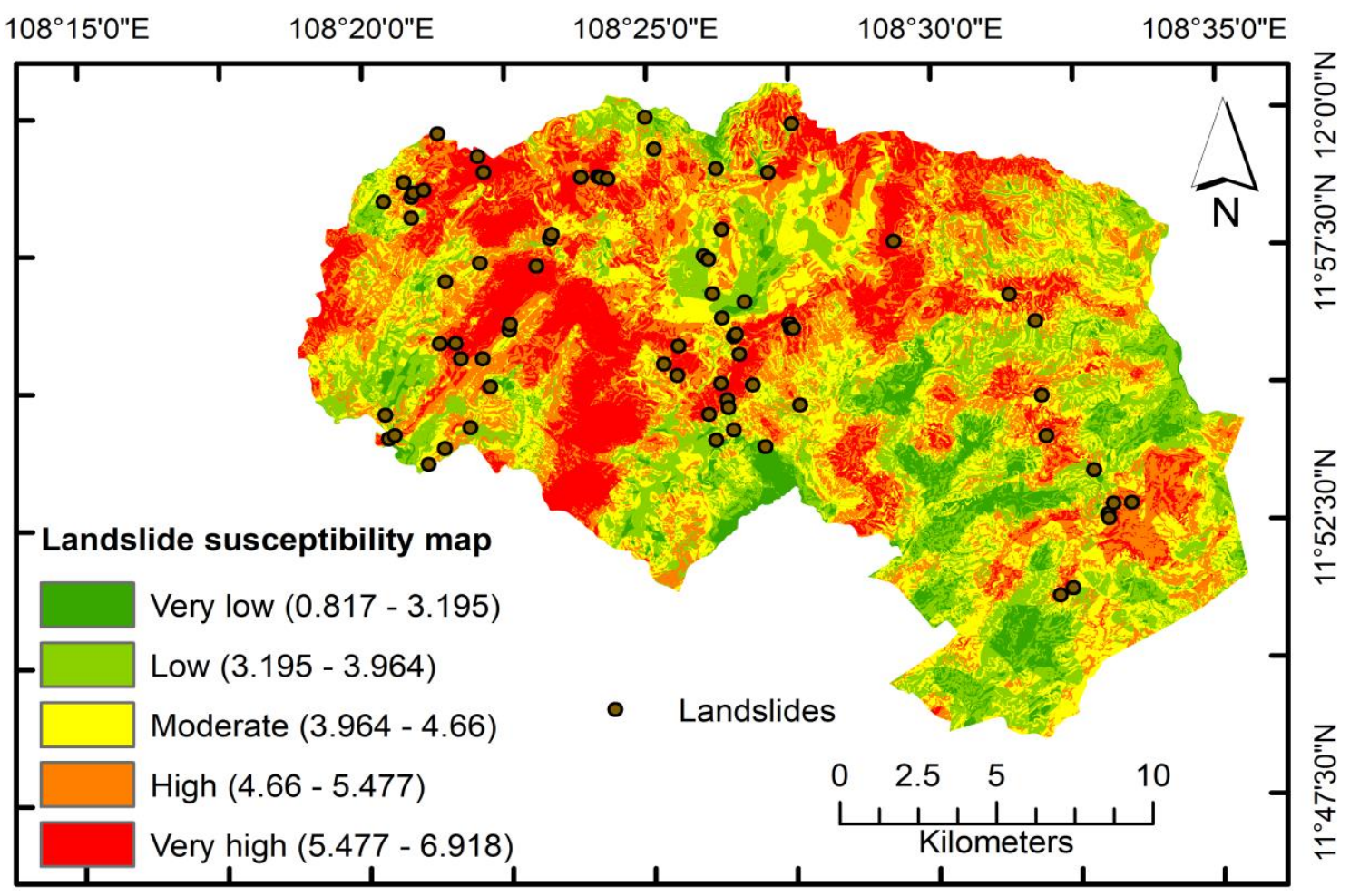

Figure 4. Landslide susceptibility map at Da Lat city using the FR method

\subsection{Validation of Landslide susceptibility map}

To validate the performance of landslide susceptibility map produced by FR method, $30 \%$ remaining landslide pixels/locations ( 21 landslide pixels), which was not used to build the map, were used to overlay with the map to calculate the probability of landslides in each susceptibility classes of the map (Fig. 5). Analysis of the map performance showed that $6.27 \%$ of the area is in the very low susceptibility area, $21.03 \%$ in the low susceptibility area, $27.09 \%$ in the moderate susceptibility area and $27.41 \%$ of the area is in the high susceptibility zone and $18.21 \%$ in the very high susceptibility zone. The validation results showed that the highest percentage of landslides observed on the map is for very high class (36.36\%) which indicates that the performance of the susceptibility map is acceptable.

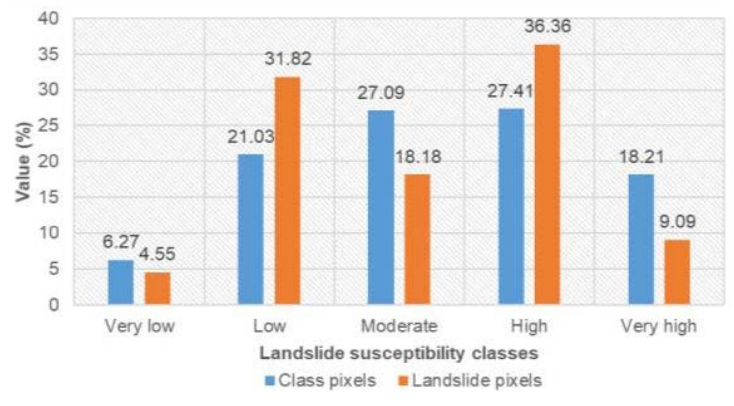

Figure 5. Distribution of pixels on the landslide susceptibility map

\section{Conclusions}

In this study, landslide susceptibility mapping was done at Da Lat city, Lam Dong province, Vietnam using FR method. To generate the landslide spatial database, a total of 72 past landslide locations and eight conditioning factors were collected and used. The results of this study showed that $6.27 \%$ of the area is in the very low susceptibility, 
Dang Quang Thanh et al./Vietnam Journal of Earth Sciences 42(2020)

$21.03 \%$ in the low susceptibility, $27.09 \%$ in the moderate susceptibility and $27.41 \%$ of the area is in the high susceptibility and $18.21 \%$ in the very high susceptibility. The validation results showed that the highest percentage of landslides observed on the map is for very high class $(36.36 \%)$. Landslide susceptibility map generated in this study would be helpful to planner and decision makers to plan future city development considering area less susceptible to landslides. However, it is proposed to consider more factors such as NDVI, curvature and aspect to improve the quality of the susceptibility map. Moreover, it would be better to compare the results of this method with the ML approaches in future studies.

\section{Acknowledgments}

This research was fully supported by the project's code TN18/T13, which belongs to the Central Highland Program No.3, Vietnam Academy of Science and Technology, Vietnam.

\section{References}

Abedini M., Ghasemian B., Shirzadi A., Shahabi H., Chapi K., Pham B.T., Bin Ahmad B., Tien Bui D., 2018. A novel hybrid approach of bayesian logistic regression and its ensembles for landslide susceptibility assessment. Geocarto International, $1-31$.

Akgun A., Dag S., Bulut F., 2008. Landslide susceptibility mapping for a landslide-prone area (findikli, ne of turkey) by likelihood-frequency ratio and weighted linear combination models. Environmental Geology, 54(6), 1127-1143.

Alkhasawneh M.S., Ngah U.K., Tay L.T., Isa M., Ashidi N., Al-Batah M.S., 2014. Modeling and testing landslide hazard using decision tree. Journal of Applied Mathematics, 1-9.

Althuwaynee O.F., Pradhan B., Lee S., 2012. Application of an evidential belief function model in landslide susceptibility mapping. Computers \& Geosciences, 44, 120-135.
Ayalew L., Yamagishi H., 2005. The application of gisbased logistic regression for landslide susceptibility mapping in the kakuda-yahiko mountains, central Japan. Geomorphology, 65(1-2), 15-31.

Barlow J., Martin Y., Franklin S., 2003. Detecting translational landslide scars using segmentation of landsat ETM+ and dem data in the northern cascade mountains, british Columbia. Canadian Journal of Resmote Sensing, 29, 510-517.

Chang K.-T., Merghadi A., Yunus A.P., Pham B.T., Dou J., 2019. Evaluating scale effects of topographic variables in landslide susceptibility models using gis-based machine learning techniques. Scientific Reports, 9(1), 1-21.

Chen W., Pourghasemi H.R., Naghibi S., 2017. A comparative study of landslide susceptibility maps produced using support vector machine with different kernel functions and entropy data mining models in china. Bulletin of Engineering Geology and the Environment, 1-18.

Constantin M., Bednarik M., Jurchescu M.C., Vlaicu M., 2011. Landslide susceptibility assessment using the bivariate statistical analysis and the index of entropy in the sibiciu basin (romania). Environmental Earth Sciences, 63(2), 397-406.

Dou J., Tien Bui D., Yunus A.P., Jia K., Song X., Revhaug I., Huan X., Zhu Z., 2015. Optimization of causative factors for landslide susceptibility evaluation using remote sensing and GIS data in parts of niigata, Japan. PLoS ONE, 10, e0133262.

Dou J., Yunus A.P., Tien Bui D., Sahana M., Chen C.W., Zhu Z., Wang W., Pham B.T., 2019a. Evaluating gis-based multiple statistical models and data mining for earthquake and rainfall-induced landslide susceptibility using the lidar dem. Remote Sensing, 11(6), 638.

Dou J., Yunus A.P., Xu Y., Zhu Z., Chen C.-W., Sahana M., Khosravi K., Yang Y., Pham B.T., 2019b. Torrential rainfall-triggered shallow landslide characteristics and susceptibility assessment using ensemble data-driven models in the dongjiang reservoir watershed, China. Natural Hazards, 97(2), 579-609.

Duc D., 2013. Rainfall-triggered large landslides on 15 december 2005 in Van Canh district, Binh Dinh province, Vietnam. Landslides, 10. 
Vietnam Journal of Earth Sciences, 42(1), 55-66

Duman T.Y., Can T., Gokceoglu C., Nefeslioglu H.A., Sonmez H., 2006. Application of logistic regression for landslide susceptibility zoning of cekmece area, istanbul, turkey. Environmental Geology, 51(2), 241-256.

Ermini L., Catani F., Casagli N., 2005. Artificial neural networks applied to landslide susceptibility assessment. Geomorphology, 66(1-4), 327-343.

Froude M., Petley D., 2018. Global fatal landslide occurrence from 2004 to 2016. Natural Hazards and Earth System Sciences, 18, 2161-2181.

Gholami M., Nekouei Ghachkanlu E., Khosravi K., Pirasteh S., 2018. Landslide prediction capability by comparison of frequency ratio, fuzzy gamma and landslide index method. Journal of Earth System Science, 128(2), 42.

Gorsevski P.V., Jankowski P., 2010. An optimized solution of multi-criteria evaluation analysis of landslide susceptibility using fuzzy sets and kalman filter. Computers \& Geosciences, 36(8), 1005-1020. http://www.sciencedirect.com/science/article/pii/S00 98300410001226.

Hasekioğulları G.D., Ercanoglu M., 2012. A new approach to use ahp in landslide susceptibility mapping: A case study at yenice (karabuk, nw turkey). Natural Hazards, 63(2), 1157-1179.

He Q., Xu Z., Li S., Li R., Zhang S., Wang N., Pham B.T., Chen W., 2019. Novel entropy and rotation forest-based credal decision tree classifier for landslide susceptibility modeling. Entropy, 21(2), 106.

Jaafari A., Najafi A., Pourghasemi H., Rezaeian J., Sattarian A., 2014. Gis-based frequency ratio and index of entropy models for landslide susceptibility assessment in the caspian forest, northern iran. International Journal of Environmental Science and Technology, 11(4), 909-926.

Kayastha P., Dhital M.R., De Smedt F., 2013. Application of the analytical hierarchy process (ahp) for landslide susceptibility mapping: A case study from the tinau watershed, west nepal. Computers \& Geosciences, 52, 398-408.

Lee S., Choi J., 2004. Landslide susceptibility mapping using gis and the weight-of-evidence model.
International Journal of Geographical Information Science, 18(8), 789-814.

Lee S., Oh H.-J., 2012. Ensemble-based landslide susceptibility maps in jinbu area, korea. Terrigenous mass movements. Springer, 193-220.

Lee S., Pradhan B., 2007. Landslide hazard mapping at selangor, malaysia using frequency ratio and logistic regression models. Landslides, 4(1), 33-41.

Lee S., Ryu J.-H., Lee M.-J., Won J.-S., 2006. The application of artificial neural networks to landslide susceptibility mapping at janghung, korea. Mathematical Geology, 38(2), 199-220.

Moosavi V., Niazi Y., 2016. Development of hybrid wavelet packet-statistical models (wp-sm) for landslide susceptibility mapping. Landslides, 13(1), 97-114.

Nguyen P.T., Tuyen T.T., Shirzadi A., Pham B.T., Shahabi H., Omidvar E., Amini A., Entezami H., Prakash I., Phong T.V., 2019. Development of a novel hybrid intelligence approach for landslide spatial prediction. Applied Sciences, 9(14), 2824.

Nguyen T.T.B., Satir M., Siebel W., Chen F., 2004. Granitoids in the dalat zone, southern vietnam: Age constraints on magmatism and regional geological implications. International Journal of Earth Sciences, 93(3), 329-340.

Nohani E., Moharrami M., Sharafi S., Khosravi K., Pradhan B., Pham B.T., Lee S.M., Melesse A., 2019. Landslide susceptibility mapping using different gisbased bivariate models. Water, 11(7), 1402.

Pham B.T., Bui D.T., Prakash I., Dholakia M., 2017. Hybrid integration of multilayer perceptron neural networks and machine learning ensembles for landslide susceptibility assessment at himalayan area (india) using gis. Catena, 149, 52-63.

Pham B.T., Jaafari A., Prakash I., Bui D.T., 2019. A novel hybrid intelligent model of support vector machines and the multiboost ensemble for landslide susceptibility modeling. Bulletin of Engineering Geology and the Environment, 78(4), 2865-2886.

Pham B.T., Prakash I., Tien Bui D., 2018. Spatial prediction of landslides using a hybrid machine learning approach based on random subspace and classification and regression trees. Geomorphology, 303, 256-270 Available from: 


\section{Dang Quang Thanh et al./Vietnam Journal of Earth Sciences 42(2020)}

http://www.sciencedirect.com/science/article/pii/S01 $69555 X 16309060$

Pham B.T., Tien Bui D., Indra P., Dholakia M., 2015. Landslide susceptibility assessment at a part of uttarakhand himalaya, india using gis-based statistical approach of frequency ratio method. Int J. Eng. Res. Technol., 4(11), 338-344.

Phong T.V., Phan T.T., Prakash I., Singh S.K., Shirzadi A., Chapi K., Ly H.-B., Ho L.S., Quoc N.K., Pham B.T., 2019. Landslide susceptibility modeling using different artificial intelligence methods: A case study at muong lay district, vietnam. Geocarto International, 1-24.

Pourghasemi H.R., Kerle N., 2016. Random forests and evidential belief function-based landslide susceptibility assessment in western mazandaran province, iran. Environmental earth sciences, 75(3), 185.

Pourghasemi H.R., Pradhan B., Gokceoglu C., 2012. Application of fuzzy logic and analytical hierarchy process (ahp) to landslide susceptibility mapping at haraz watershed, Iran. Natural Hazards, 63(2), 965-996.

Shirzadi A., Bui D.T., Pham B.T., Solaimani K., Chapi K., Kavian A., Shahabi H., Revhaug I., 2017a. Shallow landslide susceptibility assessment using a novel hybrid intelligence approach. Environmental Earth Sciences, 76(2), 60.

Shirzadi A., Tien Bui D., Pham B., Solaimani K., Chapi K., Kavian A., Shahabi H., Revhaug I., 2017c. Shallow landslide susceptibility assessment using a novel hybrid intelligence approach. Environmental Earth Sciences, 76.

Shirzadi A., Chapi K., Shahabi H., Solaimani K., Kavian A., Ahmad B.B., 2017b. Rock fall susceptibility assessment along a mountainous road: An evaluation of bivariate statistic, analytical hierarchy process and frequency ratio. Environmental Earth Sciences, 76(4), 152.

Thai Pham B., Shirzadi A., Shahabi H., Omidvar E., Singh S.K., Sahana M., Talebpour Asl D., Bin
Ahmad B., Kim Quoc N., Lee S., 2019. Landslide susceptibility assessment by novel hybrid machine learning algorithms. Sustainability, 11(16), 4386.

Thai Pham B., Tien Bui D., Prakash I., 2018. Landslide susceptibility modelling using different advanced decision trees methods. Civil Engineering and Environmental Systems, 35(1-4), 139-157.

Tien Bui D., Pradhan B., Lofman O., Revhaug I., 2012a. Landslide susceptibility assessment in vietnam using support vector machines, decision tree, and naive bayes models. Mathematical problems in Engineering, 2012.

Tien Bui D., Pradhan B., Löfman O., Revhaug I., $2012 b$. Landslide susceptibility assessment in vietnam using support vector machines, decision tree, and naive bayes models. Mathematical Problems in Engineering.

Tien Bui D., Tuan T., Klempe H., Pradhan B., Revhaug I., 2015. Spatial prediction models for shallow landslide hazards: A comparative assessment of the efficacy of support vector machines, artificial neural networks, kernel logistic regression, and logistic model tree. Landslides, 1-18.

Tran P., Trinh P., Prakash I., Singh S., Shirzadi A., Chapi K., Ly H.-B., Quoc N., Pham B., 2019. Landslide susceptibility modeling using different artificial intelligence methods: A case study at Muong Lay district, Vietnam. Geocarto International.

Xu C., Dai F., Xu X., Lee Y.H., 2012. Gis-based support vector machine modeling of earthquake-triggered landslide susceptibility in the jianjiang river watershed, China. Geomorphology, 145, 70-80.

Yao X., Tham L., Dai F., 2008. Landslide susceptibility mapping based on support vector machine: A case study on natural slopes of hong kong, china. Geomorphology, 101(4), 572-582.

Yeon Y.-K., Han J.-G., Ryu K.H., 2010. Landslide susceptibility mapping in injae, korea, using a decision tree. Engineering Geology, 116(3-4), 274-283. 